\title{
Poverty, Parental Ill Health and Children's Access to Schooling in Rural Gansu, China
}

\author{
Emily Hannum, Tanja Sargent and Shengchao Yu
}

\section{Introduction}

A substantial body of research in the social sciences has demonstrated the close relationship between health and school outcomes in developing countries (Glewwe, Jacoby, and King, 2001; Jamison, 1986). Most of these studies have focused on the health of children themselves. Potentially also important, and much less studied, is the relationship between parental health and children's schooling outcomes. This issue may be particularly important in the context of impoverished populations. Poor families may have a hard time affording health care, making parents particularly vulnerable to poor health. Parental illness can exacerbate poverty, if ill parents cannot work or if their medical bills are high.

Poverty, in turn, may curtail children's access to school, if families are unable to afford school fees. Poverty may also negatively impact school performance, if families lack resources needed to support children's education. Parental illness may also interfere with children's school performance, if a sick parent is unable to supervise children's schooling or asks a child to "replace" him or herself by spending additional time on household chores or even engaging in wage labor to compensate for household income lost. The stress of a parent's illness may also detract from ability to focus at school.

In China, catastrophic medical spending is an increasingly important cause of poverty in rural areas (Kaufman, 2005; Liu and Hsiao, 2001; Wang, Zhang and Hsiao, 2006). The problem may be particularly pronounced in China's poorest rural populations. Little research has addressed how children are affected by the health problems experienced by parents. In this paper, we focus on Gansu Province, one of China's poorest. We investigate whether and in what ways parental illness poses a risk for children's schooling. After providing a motivation for this topic and an introduction to Gansu Province and our data, we address five questions: First, does poverty coincide with poor parental health? Second, is parental illness a risk factor for enrollment? Third, is there evidence of an economic mechanism for the link between parental illness and children's enrollment? Fourth, are children with ill parents more likely to work, in order to substitute for the labor of sick parents? Finally, do children with ill parents exhibit lower school attendance or performance? 


\section{Motivation}

Interestingly, the abundant literature on health and education in developing countries has paid little attention to the issue of how parental health might matter for children's schooling. ${ }^{1}$ One notable exception is the growing body of literature on the effects of AIDS-related parental mortality and children's schooling outcomes. Ainsworth, Beegle and Koda (2005) review this literature and consider the impact of parental deaths from AIDS on children's primary schooling outcomes in Tanzania. Ainsworth, Beegle and Koda (2005) emphasize several reasons for the educational problems faced by children when their parents take ill or pass on: a reduced ability to pay school fees when faced with expensive medical and funeral bills; heightened demand for the child's time to care for or substitute for the work of the critically ill adult; lack of interest by (non-parent) guardians in investing in the long-term welfare of orphans; and emotional and psychological damage to a child witnessing his/her parent's death after a long illness. The impact on children's long-term educational chances brought about by the tragic AIDS situation in many countries may be an extreme case of a broader phenomenon of children's vulnerability to parental health problems.

\section{Adult Health, Poverty, and Enrollment}

Why might parental health problems affect access to schooling, or at least signal vulnerability to non-enrollment? We consider this question in general, and then for the case of China. An important consideration is that poor health is a mark of poverty in many countries. ${ }^{2}$ Wagstaff (2002) highlights the extent to which ill-health and poverty are intertwined. Poverty heightens the risk of ill-health through prolonged exposure to poor nutrition, poor sanitation, and unsafe or unhealthy living and working environments. Moreover, the socially disadvantaged tend to have less access to quality health care, and may be less able to make use of available health care services (Fiscella et al., 2000). The lack of access to health care for disadvantaged populations may be especially severe in developing countries (Wagstaff, 2002), strengthening the link from poverty to health problems. Thus, children of the poor may face heightened risk of having a parent with a health problem. From another perspective, children of parents with significant health problems may be more likely to be poor, and thus vulnerable when school costs are high.

A second consideration is that ill-health may not only signal poverty, but actually lead to poverty, as a result of catastrophic health care costs or loss of income due to inability to carry out daily activities. Many studies have attested to the impact of health on individual productivity and wage earning capacity. For example, Thomas and Strauss (1997) investigate the effects of health on labor productivity in low-income countries, including the relationship between health indicators (body mass index and nutrition) on wages in urban Brazil. They conclude that health yields substantial returns in the formal sector of Brazilian labor markets. Using data from the

\footnotetext{
${ }^{1}$ Much of the research looking at links between health and children's education outcomes has focused on the effects of children's health and nutrition. See, for example, Alderman et al. (2001), Behrman (1996), and Glewwe (2005). For evidence from China and rural Gansu, see Yu and Hannum (2007).

${ }^{2}$ For a comprehensive review of the literature on the relationship between health and economic development, see Strauss and Thomas (1998).
} 
Living Standards Measurement Surveys in Ghana and Cote d'Ivoire, Schultz and Tansel (1997) also attest to a connection between illness and lower wages.

The relationship between ill-health and poverty suggests a vicious cycle: poverty leads to poor health outcomes, which lead to loss of wages and increased expenditure on health care. Loss of wages and health expenditures contribute to poverty, further exacerbating vulnerability to catastrophic illness. The cycle of ill-health and poverty may curtail a family's capacity to afford children's education, reducing chances for children to escape the cycle of poverty and ill health that afflicts their parents.

\section{Other Mechanisms of Impact}

An additional pathway by which parental illness might affect children's educational opportunities could occur if, when a parent is ill, a child substitutes for his or her paid or household labor. ${ }^{3}$ While there are debates about whether or not child work is inherently bad for children, research in some settings suggests that few children combine work and schooling, and that child work competes with subsequent schooling (Beegle, 2005; Blunch, 2006).

Parental illness may also interfere with children's education through the social environment at home. For example, a sick parent may be less able to supervise children's schooling or interact with the child to provide educational and emotional supports. These factors could detract from attendance or performance. An impact on attendance or performance could also emerge if a student is unable to concentrate at school, due to distress or depression related to family health circumstances. Finally, impact on attendance or performance could emerge if children are spending time substituting for the labor of ill household members, and are thus distracted from a focus on school. To our knowledge, these other mechanisms by which parental health could impact children's schooling have not been investigated in China.

\section{Research Questions}

In this paper, we investigate the relationship between parental health and children's schooling. We consider the following questions: First, does poverty coincide with poor parental health? Are children in poorer households at higher risk of having ill parents? Second, is parental illness a risk factor for enrollment? If parents who fall ill are unable to work to support the family, or if the family spends a lot of money on medical bills, the family may become poorer and less able to afford school fees, necessitating pulling children from school.

Third, is there evidence of an economic mechanism for the link between parental illness and children's enrollment? For example, if this were the case, we would expect to see that the link weakens with controls for wealth; that households with ill parents make smaller investments in education, and that parents with illness are more likely to borrow to support their children's education. Fourth, we consider whether children with ill parents are more likely to work, in order to substitute for the labor of sick parents. Finally, we consider whether children with ill parents exhibit lower school attendance or performance.

\footnotetext{
${ }^{3}$ There is a vast literature on the factors related to child labor. For one example, see Ersado (2005).
} 


\section{China and Gansu Context}

\section{Policy Trends in China}

Links among health, poverty and educational access are of particular interest in China at present, given policy reforms in recent decades that have raised costs to individuals for accessing both the health care and educational systems, and more recent efforts to address cost barriers. The health care system has undergone a radical privatization under market reforms (Blumenthal and Hsiao, 2005). On the eve of market reforms, public health institutions were financed by the government, and public health services were provided to users at little or no cost (Liu and Mills, 2002). By 1975, insurance coverage provided by the government, state enterprises, and the rural cooperative medical system had reached close to 90 percent of the population (Hsiao et al., 1997). This coverage included almost all of the urban population and 85 percent of the rural population. It provided access to both cost-effective preventive and curative health care services (Hsiao et al, 1997).

With market reforms came many changes. The cooperative medical system, no longer supported by collective farming income, disintegrated, leaving the majority of rural residents without medical insurance. In urban areas, the breakdown of the state-owned enterprise system left many uninsured (Beach, 1997; Gao et al., 2001). At the same time, the state reduced public funds channeled to health care and encouraged public health institutions to see themselves as economic bodies and to operate on a fee-for-service basis, and rural health stations that once provided free medical care were transformed into fee-for-service health clinics (Beach, 1997; Liu and Mills, 2002).

Overall, reforms have coincided with increased health care spending. From 1979 to, 2004, the average total health expenditure per person increased nearly eight-fold, from 9 USD to 70 USD (Office of the World Health Organization Representative in China, and Social Development Department of the State Council Development Research Group, 2005:19). From 1978 to 2002, national spending on health care of all types (including public health) rose from 3.0 percent to nearly 5.5 percent of GDP (Blumenthal and Hsiao, 2005). However, from 1978 to 1999, the central government's share of national health care spending fell from 32 percent to 15 percent (Blumenthal and Hsiao, 2005). Government budgetary expenditures as a proportion of total expenditures for public health hovered between 15 and 17 percent between 1997 and 2003 (National Bureau of Statistics, 2006: Table 22-37).

The financing gap that resulted from the reform was filled mainly by private out-of-pocket spending (Hsiao et al., 1997). Overall, out-of-pocket payments rose from 20 percent of the health sector's revenue in 1978 to 26 percent in 1986 to 42 percent in 1993 (Hsiao et al., 1997). Out-ofpocket expenses accounted for 58 percent of health care spending in China in 2002 (Blumenthal and Hsiao, 2005). By 2004, 60 percent of total health care costs were paid out of pocket, and the rate of out of pocket payment was as high as 90 percent in rural areas (Office of the World Health Organization Representative in China, and Social Development Department of the State Council Development Research Group, 2005: 14). Between 1985 and 2004, rural health care and medical services expenditures per capita rose from 2 percent to 6 percent of total consumption per capita (see Figure 1). 


\section{Figure 1. Health Care and Medical Services as a Share of Rural Household Consumption Expenditures}

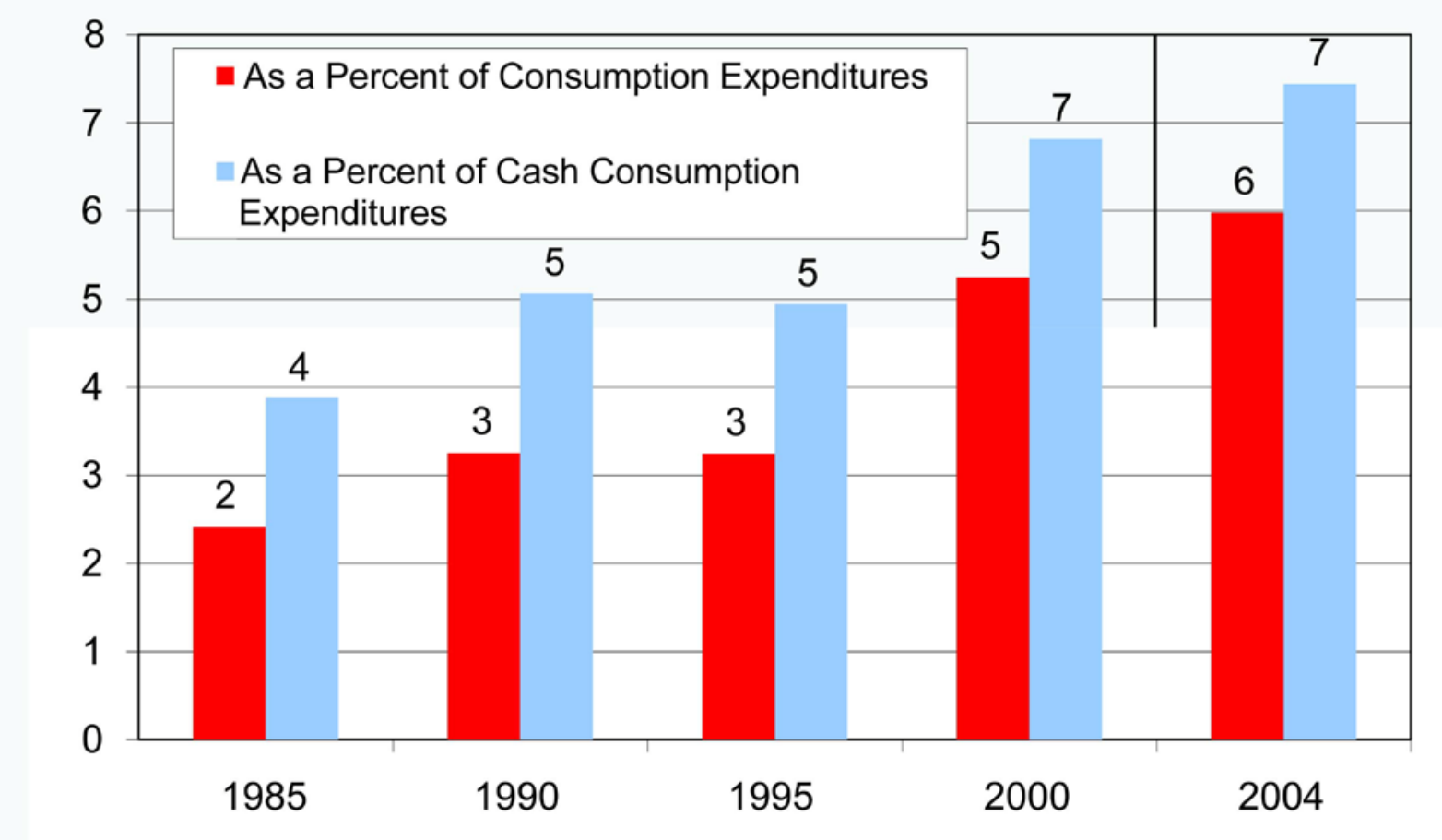

Source: China Statistics Yearbooks 1996, Table 9-19 and 2005, Table 10-25. Beijing: National Bureau of Statistics.

Some evidence suggests that an increased reliance on individual resources has resulted in growing inequities in access to health. In 2004, infant, maternal, and under-five mortality rates in rural areas were three times those in the cities, and under-five mortality rates in the poorest rural areas actually increased in the early 2000s (Office of the World Health Organization Representative in China, and Social Development Department of the State Council Development Research Group 2005: Figure 2.4).

Cost barriers are a significant contributing factor. As of 2003, 80 percent of the rural population and half the urban population were not covered by any insurance schemes (Office of the World Health Organization Representative in China, and Social Development Department of the State Council Development Research Group, 2005: 14). Gustafsson and Li (2005) find that the percentage of the household budget in rural China spent on health and education in 1995 was much larger than it was in 1988, with households in western China and officially designated poor areas being hardest hit (Gustafsson and $\mathrm{Li}, 2004$ ). In a 2001 survey of residents in three provinces, half of the respondents said that they had foregone health care in the previous 12 months because of its cost (Blumenthal and Hsiao, 2005). A 2003 National Health Services Survey indicates that half of respondents refused outpatient services when sick and 30 percent of 
those referred to inpatient care refused hospitalization. 38 percent of those who did not seek medical attention when sick, and 78 percent of those who refused hospitalization upon referral, cited inability to pay (Office of the World Health Organization Representative in China, and Social Development Department of the State Council Development Research Group, 2005: 14).

One consequence of rising health care costs is that catastrophic medical spending is an increasingly important precipitant of poverty in rural areas (Kaufman, 2005; Liu and Hsiao, 2001; Wang, Zhang and Hsiao, 2006). Liu, Rao and Hsiao (2003) estimate the impact of medical expenditures on the poverty headcount in rural areas, and found that out-of-pocket spending on healthcare raised the number of rural households living below the poverty line by 44 percent. Another multi-province panel study showed that large declines in self-assessed health of household heads ${ }^{4}$ led to, on average, a reduction in income of 12 percent, and increases in medical expenditures by 17 percent (Lindelow and Wagstaff, 2005). Moreover, there are clear implications for the education of children: analyses of a 2002 survey of households in six townships in Guizhou and Shanxi Provinces showed that, compared to households without hospitalization, households with hospitalization had a reduction in educational expenditures of 26 percent (Wang, Zhang and Hsiao, 2006).

Importantly, some of the reform-era changes in the health sector have parallels in the education sector; in particular, costs to households have risen. One of the most important changes that occurred in the education policy realm after the end of the Cultural Revolution was decentralization of the administration and finance of primary, secondary and tertiary education (Hawkins, 2000; Tsang, 2000). A major objective of finance reform in education was to mobilize new resources for education, and substantial privatization of costs was an important consequence (Hawkins, 2000; Tsang, 2000).

The objective of mobilizing new resources appears to have been achieved. Tsang (2000: 14) shows that in 1986 constant prices, governmental budgeted funds for education increased from 26.50 billion RMB in 1986 to 48.63 billion RMB in 1997, translating to an average annual real growth rate of 5.7 percent. In the same period, extra-budgetary funds grew much faster, from 8.13 billion RMB in 1986 to 40.25 billion RMB in 1997, translating to an average annual real growth rate of 15.7 percent. Tuition and fees alone grew from 4.42 percent of educational expenditures in 1991 to about 18.06 percent by 2003 (Hannum et al., 2008, Table 2). In the most recent years, concerns about effects of cost barriers at the stage of compulsory education have led to efforts to eliminate school fees (e.g., CERNET, 2005a; CERNET, 2005b).

In short, in both the health and education sectors, finance changes in the reform period through the early 2000s raised the salience of individuals' ability to pay for services. These changes have emerged in the context of unprecedented prosperity in China, but they have also coincided with rising regional and household income inequalities. As costs associated with both health and education have risen, these changes raise the possibility that health shocks to families could be an important factor curtailing educational access for children.

\footnotetext{
${ }^{4}$ Household shocks were measured in terms of downward movement of two categories in self-assessed health.
} 


\section{The Case of Gansu Province}

Cost barriers to health and education are likely to be most salient in the poorest regions of China. Poverty in China is heavily concentrated in rural areas, and rural poverty is much more prevalent in the interior and western provinces than in the coastal provinces (Wang, 2004). This study takes place in Gansu, one of China's poorest provinces. In 2001, Gansu was ranked second-tolast among provinces in per capita GDP, with a figure that was only 55 percent of China's national average (Woo and Bao, 2003). By China's official poverty estimates for the same year, the rate of poverty in Gansu was three times the national average, and Gansu was home to 6.64 percent of China's poor rural population (Wang, 2004).

Gansu stretches across desert, mountainous and hilly areas, and vast grasslands. Much of Gansu is mountainous or highland plateau, with an elevation of more than 1,000 meters (UNESCAP, 2005). In the year 2000, Gansu Province had a population of 25.62 million, 76 percent of whom resided in rural areas (UNESCAP, 2005). Gansu is thus not representative of China as a whole, but it targets the subpopulation in which we would expect to see that health-related costs presented a significant burden for the financing of children's education.

\section{Data and Methods}

\section{Data Set}

Data for our main analysis come from the Gansu Survey of Children and Families, wave 2 (GSCF-2), a survey conducted in Gansu Province in the summer of 2004. The first wave of the survey was conducted among children ages 9-12 in the year $2000(\mathrm{~N}=2000)$. The GSCF employed a multi-stage cluster sample, selecting first rural counties, then townships, then villages, and finally children, along with their mothers, fathers, and homeroom teachers. GSCF-2 interviewed almost all of the same children at ages 13 to $16(\mathrm{~N}=1915)$, and added a significant health component to the study. Our sample for this study consists of all sample children. ${ }^{5} \mathrm{We}$ also present a supplementary analysis of educational spending in households in 2004, using indicators of parental health, wealth, number of children in the household, and educational spending in the year 2000 .

\section{Variables}

\footnotetext{
${ }^{5}$ The household questionnaire for the GSCF is based on the sample children, who are linked to information about their mothers and fathers. In some cases, parents are deceased or do not reside in the same household. 36 children (1.93 percent) have deceased fathers, and 17 children ( 0.89 percent) have deceased mothers. Only one child has lost both parents. Information is available on living parents even when they are not currently residing in the household. Of the sample of 1,915 children, 93.47 live at home or at school, or a combination of the two. 6.53 percent of the children live elsewhere. Of those children who live outside the household, 11.20 percent report that they live elsewhere in order to have access to better schooling and 76.80 percent report they live elsewhere in order to work. All of the children living outside the household are included in our analytic sample.
} 
Children's education and work status: Children's education outcomes are measured using five variables: enrollment, attendance, child work status, time spent on household chores and academic performance.

Enrollment: The measure of current enrollment is a dummy variable that is coded as 1 if child is currently enrolled, and is otherwise coded as 0 .

Attendance: We include a dummy variable measuring school absence. The variable is coded as 1 if child missed school during the past semester, and 0 if not.

Child work status and time spent on household chores. The indicator of whether or not the child is working for wages comes from a questionnaire item that asks about type of work engaged in by household members. If a child is reported as being engaged in some type of wage labor, this variable is coded as 1 . It is otherwise coded as 0 . Among our sample children, 8 percent are reported by the household head to be engaged in some type of wage labor. 48 percent of children working in wage labor are engaged in the service industry.

We also include a separate variable that measures hours per week spent on housework such as cooking, washing clothes, chopping firewood, carrying water, caring for the elderly and the sick, and helping children with homework. This variable is generated from a household time allocation table. 71.96 percent of the children in our sample report being involved in housework.

Academic performance: We measure academic achievement using homeroom teacher's reports of the most recent math and Chinese scores available.

Parental health status. We use four indicators of parental health status: general health status, chronic illness/disability, and disability alone.

General health status is a report by the household head (usually the child's father) on health of the child's mother and father. The question was worded as follows: 'In general, how would you describe the state of his/her health?” Original wording on the 2000 and 2004 questionnaires offered five possible responses: very poor, fairly poor, average, fairly good, and very good. For ease of analysis, responses were grouped into three categories: poor, average, and good. In some models, we use a dichotomous specification of poor health versus other. We use separate variables for mother and father's health.

Illness/disability is a dummy variable coded as one if either parent suffers from a chronic illness (cancer, heart disease, diabetes, hepatitis or other) or a disability (deafness, blindness, mental illness, bodily disability, retardation, or other disability) in the 2004 data. For the household analysis, which uses the 2000 version of this variable, the chronic illness component was worded differently. It asked if the household member saw a doctor for a chronic illness in the past year. The dummy variable for the household analysis was coded as on if a parent had a chronic illness (by this definition) or a disability (measured in the same way as in 2004). 
Disability is a dummy variable coded as one if either parent suffers from a physical or mental disability such as deafness, blindness, mental illness, bodily disability, retardation, or other disability, in both 2000 and 2004.

Household socio-economic status. Our analysis of the GSCF data uses two variables as indicators of socioeconomic status in 2004: a household assets measure and a parental education measure. Our household assets measure is generated by summing the value of the list of durable goods owned by the family. In our household level analysis, our measure of socioeconomic status in 2000 is a constructed measure of household wealth.

Socio-demographic background. Parental education is measured as the total number of years of education obtained by the child's mother and father. (In our descriptive tables, we present years of mothers' and fathers' education separately, and as categorical variables.) We also include three child demographic variables: gender, sibship size, and child age. Sibship size is the number of siblings that the sample child has, whether or not coresident. In the household analysis, the parallel measure used in the year 2000 is siblings plus one, to include the target child.

Household educational expenditures and borrowing. We include measures of household educational expenditures in the preceding year (measured both in 2000 and 2004), and household reports of whether or not they borrow money to pay for children to go to school (in 2004).

\section{Analysis}

\section{Links between Parental Health and Poverty}

The first question that we ask with the GSCF data is whether parental health problems are associated with poverty. Table 1 shows the percent of children in households with each type of parental health problem, tabulated by household assets quintile and by father's and mother's educational attainment levels. 
Table 1. Parental Health and Parental Socioeconomic Status

\begin{tabular}{|c|c|c|c|c|c|c|c|c|c|}
\hline & \multirow[t]{2}{*}{ Total } & \multicolumn{6}{|c|}{ General Health Status } & \multirow{2}{*}{\begin{tabular}{|l}
$\begin{array}{c}\text { Parent is } \\
\text { sick or } \\
\text { disabled }\end{array}$ \\
$\%$ Yes
\end{tabular}} & \multirow{2}{*}{\begin{tabular}{|l|}
$\begin{array}{c}\text { Parent is } \\
\text { disabled }\end{array}$ \\
\\
Yes
\end{tabular}} \\
\hline & & $\begin{array}{l}\text { Mother } \\
\% \text { Poor }\end{array}$ & \% Ave. & \%Good & $\begin{array}{l}\text { Father } \\
\% \text { Poor }\end{array}$ & \% Ave. & \% Good & & \\
\hline Total & & 10.25 & 24.67 & 65.08 & 8.57 & 20.65 & 70.78 & 11.96 & 6.53 \\
\hline Household assets quintile & $(\mathrm{N}=1,915)$ & $(\mathrm{N}=194)$ & $(\mathrm{N}=467)$ & $(\mathrm{N}=1,232)$ & $(\mathrm{N}=161)$ & $(\mathrm{N}=388)$ & $(\mathrm{N}=1,330)$ & $(\mathrm{N}=229)$ & $(\mathrm{N}=125)$ \\
\hline 1--poorest & 20.10 & 18.40 & 25.07 & $56.53 * *$ & 14.40 & 27.72 & $57.88 * *$ & $20.26 * *$ & $12.47 * *$ \\
\hline 2 & 19.95 & 12.43 & 25.40 & 62.17 & 8.06 & 20.97 & 70.97 & 11.78 & 6.28 \\
\hline 3 & 20.00 & 9.26 & 23.02 & 67.72 & 7.92 & 17.41 & 74.67 & 12.79 & 7.31 \\
\hline 4 & 19.95 & 5.80 & 27.97 & 66.23 & 6.35 & 23.02 & 70.63 & 8.90 & 3.14 \\
\hline 5--richest & 20.00 & 5.48 & 21.93 & 72.58 & 6.28 & 14.40 & 79.32 & 7.83 & 3.92 \\
\hline Mother's education & $(\mathrm{N}=1,897)$ & $(\mathrm{N}=194)$ & $(\mathrm{N}=467)$ & $(\mathrm{N}=1,232)$ & $(\mathrm{N}=159)$ & $(\mathrm{N}=381)$ & $(\mathrm{N}=1,322)$ & $(\mathrm{N}=227)$ & $(\mathrm{N}=123)$ \\
\hline Less than primary & 47.05 & 14.05 & 22.07 & $63.88 * *$ & 11.02 & 18.86 & $70.11+$ & 13.76 & 7.44 \\
\hline Primary & 33.84 & 7.32 & 27.26 & 65.42 & 6.47 & 22.40 & 71.14 & 10.75 & 5.92 \\
\hline Middle & 16.71 & 5.68 & 25.87 & 68.45 & 6.05 & 21.34 & 72.61 & 8.83 & 4.42 \\
\hline High School & 1.90 & 8.33 & 33.33 & 58.33 & 6.06 & 18.18 & 75.76 & 16.67 & 11.11 \\
\hline Tertiary & 0.05 & 0.00 & 0.00 & 100.00 & 0.00 & 0.00 & 100.00 & 0.00 & 0.00 \\
\hline Father's education & $(\mathrm{N}=1,877)$ & $(\mathrm{N}=191)$ & $(\mathrm{N}=454)$ & $(\mathrm{N}=1,212)$ & $(\mathrm{N}=161)$ & $(\mathrm{N}=388)$ & $(\mathrm{N}=1,328)$ & $(\mathrm{N}=226)$ & $(\mathrm{N}=124)$ \\
\hline Less than primary & 20.99 & 15.76 & & $61.24 * *$ & 14.72 & 17.01 & $68.27 * *$ & $15.99 *$ & $9.64 *$ \\
\hline Primary & 33.83 & 10.03 & 24.04 & 65.92 & 7.87 & 22.36 & 69.76 & 11.81 & 5.98 \\
\hline Middle & 32.51 & 7.05 & 26.12 & 66.83 & 5.72 & 21.14 & 73.13 & 9.06 & 4.93 \\
\hline High School & 10.87 & 9.85 & 23.15 & 67.00 & 8.33 & 21.08 & 70.59 & 13.73 & 7.84 \\
\hline Tertiary & 0.80 & 20.00 & 26.67 & 53.33 & 0.00 & 20.00 & 80.00 & 20.00 & 6.67 \\
\hline
\end{tabular}

Source: Wave 2 GSCF, 2004 
Table 1 shows that children in the poorest quintile were more than three times as likely as children in the wealthiest to have a mother who reported poor health (18.40 percent versus 5.48 percent), and over twice as likely to have a father who reported poor health (14.40 percent versus 6.28 percent). Similarly, about eight percent of children in the richest quintile lived in households with a chronically sick or disabled parent, compared to over 20 percent of children in the poorest quintile. Just 3.92 percent of the wealthiest children lived in a house with a disabled parent, compared to 12.47 percent of the poorest children. Tabulations of parental health problems by father's and mother's educational attainment levels sometimes show a pattern of fewer health problems among households with more educated parents, but the relationship is not as consistent as for family wealth. This finding makes sense, if economics, more than information, is the driving factor in lack of access to health care. (In addition, there are very few households with college-educated mothers or fathers, and thus results for these categories are not always consistent.)

\section{Parental Health as a Risk Factor for Enrollment}

Are parental health problems associated with children's school enrollment? Table 2 shows children's percent enrolled, percent absent in the past semester, percent working for wages, average hours spent on housework in the past week, and school performance in math and Chinese by parental general health status, chronic sickness and disability status, and disability status alone. On average, 81.96 percent of children whose mothers had poor general health were enrolled, compared to about 88 percent of children whose mothers reported average or good health, though these results were only marginally significant. 
Table 2. Child Schooling and Work Outcomes by Parental Health Status

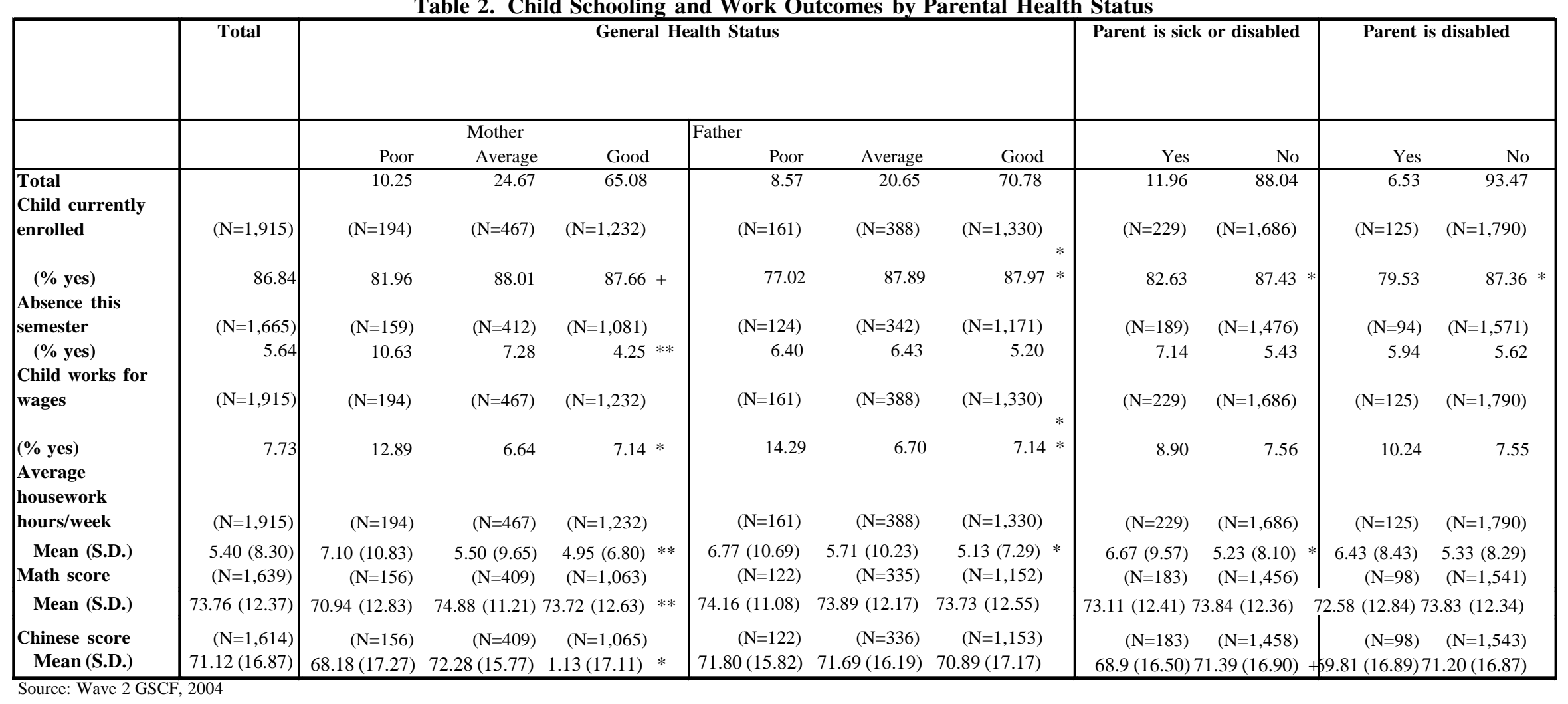


Comparable figures for fathers were more striking: just 77.02 percent of children whose fathers reported poor health were enrolled, compared with about 88 percent of children of fathers with average or good health. Turning to other health measures, about 83 percent of children with a chronically sick or disabled parent are enrolled, compared to about 87 percent of children with well parents. The disadvantage for children with disabled parents is more striking: about 80 percent of these children are enrolled, compared to 87 percent of children without disabled parents. These descriptive results suggest, at least, that children in poor households were at heightened risk of parental illness, and that children in households with ill parents were at heightened risk of reduced enrollment.

We can conservatively interpret the tables just shown to state that poor parental health is a moderate risk factor for poor enrollment outcomes for children in rural Gansu. Getting to the point of saying that poor parental health causes these poorer outcomes is a more challenging task, given that there might be factors, such as chronic poverty, that would be deleterious to parental health and also place children at higher educational risk. In the models below, we partially address this concern by looking at whether the health effects that appear in the descriptive tables persist in multivariate models that control for a number of socio-demographic and economic variables. In general, we first show the bivariate relationship between the schooling outcome and the parental health outcome. Second, we include child background characteristics: age, age squared, number of siblings, and total years of parental education.

Finally, we add the natural log of household assets into the model to control for household socioeconomic status. Because we anticipate that a major mechanism of parental health effects on children's schooling is economic, we would expect to see that specifications that include a proxy for wealth would reduce the magnitude or statistical significance of the parental health measures. 
Table 3a. Selected Logit Models of Enrollment with General Health Status of Mother (Panel A) and father (Panel B)

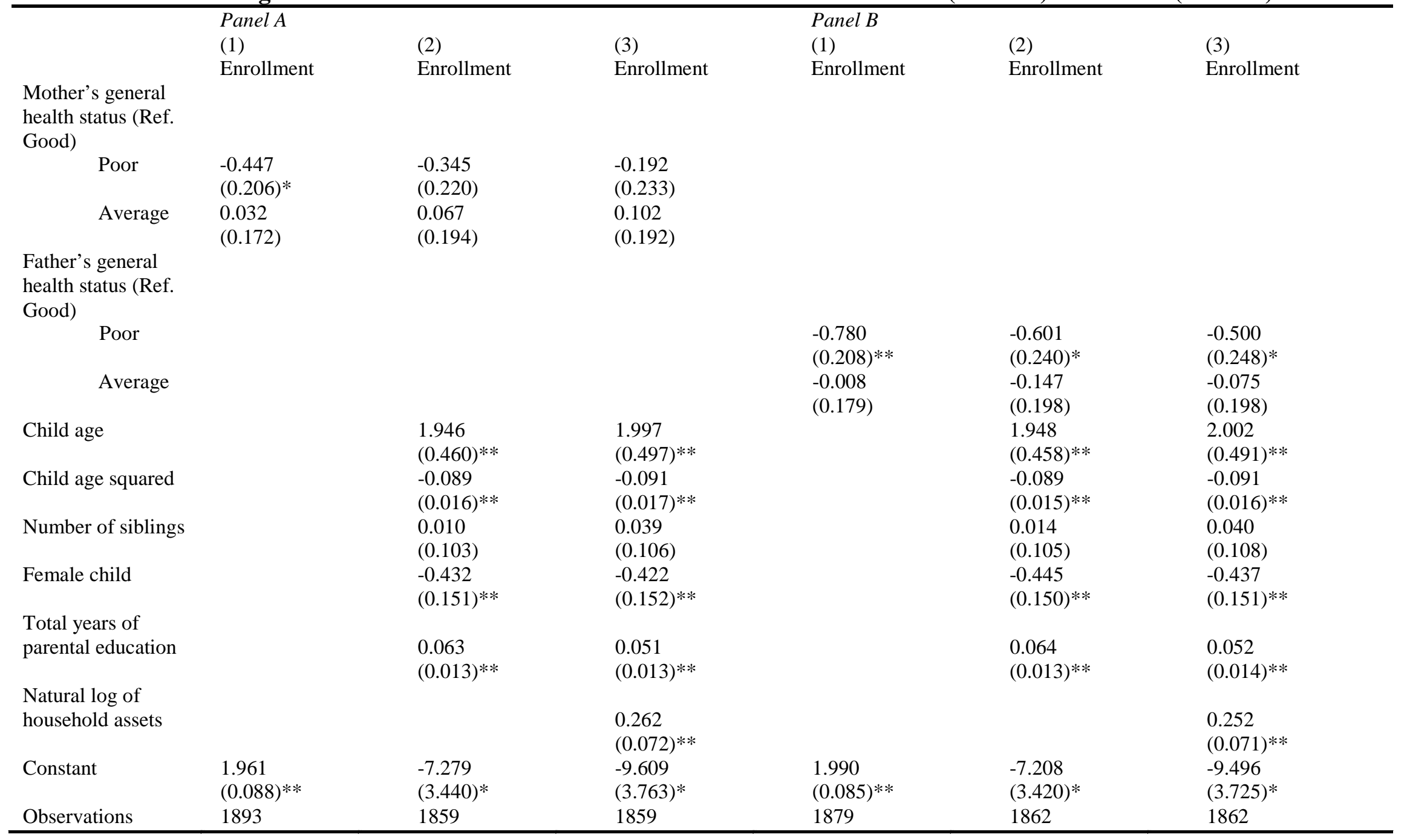

Robust standard errors in parentheses; + significant at 10\%; * significant at 5\%; ** significant at 1\% 
Table 3b. Selected Logit Models of Enrollment with Parental Disability (Panel A) and Parental Illness/Disability (Panel B)

\begin{tabular}{|c|c|c|c|c|c|c|}
\hline & $\begin{array}{l}\text { Panel A } \\
\text { (1) }\end{array}$ & $(2)$ & (3) & $\begin{array}{l}\text { Panel B } \\
\text { (1) }\end{array}$ & $(2)$ & (3) \\
\hline Parent is disabled & $\begin{array}{l}\text { Enrollment } \\
-0.543 \\
(0.240)^{*}\end{array}$ & $\begin{array}{l}\text { Enrollment } \\
-0.615 \\
(0.261)^{*}\end{array}$ & $\begin{array}{l}\text { Enrollment } \\
-0.489 \\
(0.271)+\end{array}$ & Enrollment & Enrollment & Enrollment \\
\hline $\begin{array}{l}\text { Parent is sick or } \\
\text { disabled }\end{array}$ & & & & $\begin{array}{l}-0.422 \\
(0.189)^{*}\end{array}$ & $\begin{array}{l}-0.461 \\
(0.208)^{*}\end{array}$ & $\begin{array}{l}-0.366 \\
(0.216)+\end{array}$ \\
\hline Child age & & $\begin{array}{l}1.962 \\
(0.460)^{* *}\end{array}$ & $\begin{array}{l}2.013 \\
(0.493)^{* *}\end{array}$ & & $\begin{array}{l}1.970 \\
(0.458)^{* *}\end{array}$ & $\begin{array}{l}2.020 \\
(0.491)^{* *}\end{array}$ \\
\hline Child age squared & & $\begin{array}{l}-0.090 \\
(0.016)^{* *}\end{array}$ & $\begin{array}{l}-0.092 \\
(0.017)^{* *}\end{array}$ & & $\begin{array}{l}-0.090 \\
(0.015)^{* *}\end{array}$ & $\begin{array}{l}-0.092 \\
(0.016)^{* *}\end{array}$ \\
\hline Number of siblings & & $\begin{array}{l}0.017 \\
(0.103)\end{array}$ & $\begin{array}{l}0.043 \\
(0.106)\end{array}$ & & $\begin{array}{l}0.016 \\
(0.104)\end{array}$ & $\begin{array}{l}0.042 \\
(0.107)\end{array}$ \\
\hline Female child & & $\begin{array}{l}-0.455 \\
(0.151)^{* *}\end{array}$ & $\begin{array}{l}-0.444 \\
(0.152)^{* *}\end{array}$ & & $\begin{array}{l}-0.442 \\
(0.151)^{* *}\end{array}$ & $\begin{array}{l}-0.435 \\
(0.152)^{* *}\end{array}$ \\
\hline $\begin{array}{l}\text { Total years of } \\
\text { parental education }\end{array}$ & & $\begin{array}{l}0.066 \\
(0.013)^{* *}\end{array}$ & $\begin{array}{l}0.054 \\
(0.013) * *\end{array}$ & & $\begin{array}{l}0.066 \\
(0.013)^{* *}\end{array}$ & $\begin{array}{l}0.054 \\
(0.013)^{* *}\end{array}$ \\
\hline $\begin{array}{l}\text { Natural log of } \\
\text { household assets }\end{array}$ & & & $\begin{array}{l}0.254 \\
(0.071)^{* *}\end{array}$ & & & $\begin{array}{l}0.255 \\
(0.071)^{* *}\end{array}$ \\
\hline Constant & $\begin{array}{l}1.929 \\
(0.073)^{* *}\end{array}$ & $\begin{array}{l}-7.333 \\
(3.439)^{*}\end{array}$ & $\begin{array}{l}-9.598 \\
(3.734)^{*}\end{array}$ & $\begin{array}{l}1.945 \\
(0.075)^{* *}\end{array}$ & $\begin{array}{l}-7.390 \\
(3.419) *\end{array}$ & $\begin{array}{l}-9.656 \\
(3.722)^{* *}\end{array}$ \\
\hline Observations & 1915 & 1862 & 1862 & 1915 & 1862 & 1862 \\
\hline
\end{tabular}

Robust standard errors in parentheses; + significant at 10\%; * significant at 5\%; ** significant at $1 \%$

Source: Wave 2 GSCF, 2004 
Tables 3a and b show multivariate models of enrollment, using the parental health variables measuring parent's general health status, and parental disability, and chronic illness or disability. For each set of analyses, Model 1 is a bivariate model, containing only the parental health measure and enrollment. Model 2 adds a basic set of socio-demographic variables: child's age and age squared, sibship structure, child sex, and parental education. Model 3 adds to Model 2 a measure of logged household assets.

Table 3a shows that, for mother's general health status (Panel A), only the bivariate model yields a coefficient that is significant at conventional levels. In contrast, striking results emerge for father's general health status (Panel B). The odds of enrollment for children whose fathers report poor health are 54 percent lower than those of children of fathers with good health, without other controls. This unadjusted model is simply another way to portray the bivariate relationship described in Table 2. The coefficients in Model 1 mean that about 77 percent of children with a father with poor health are enrolled, compared to 88 percent of children with a father not in poor health. By presenting this baseline model, we are able to investigate how the illness disadvantage differs in models that adjust for compositional differences distinguishing households with and without ill parents. In models that control for socio-demographic variables, the odds reduction is 45 percent, and with logged assets, 39 percent. The general health status measure is significant at the 5 percent level or better, across all specifications. The stronger results for fathers' general health than for mothers' are not surprising, if father's health is more determinant of family socioeconomic status than mother's health.

Table 3b shows that, compared to children in households with well parents and without controlling for any other variables, children in households where a parent is disabled have 42 percent lower odds of being in school, and children in households where a parent is chronically sick or disabled have 34 percent lower odds of being in school. These odds mean that about 80 percent of children in households with a disabled parent were enrolled, compared to about 87 percent of children in households without. Comparable numbers for the sickness or disability measure were 82 and 87 percent.

For both health measures in Table 3b, Model 2, which controls for socio-demographic variables that are unlikely to change in response to illness, heightens these effects. For example, children in households where a parent is disabled have 46 percent lower odds of being in school, and children in households where a parent is chronically sick or disabled have 37 percent lower odds of being in school, than children in households with well parents. As anticipated, with the addition of a wealth measure in Model 3, the parental disability variable and the parental chronic illness or disability variable drop to marginal significance, and are reduced in magnitude.

\section{Evidence of the Economic Impact of Ill Health}

$\underline{\text { Parental Ill Health and Subsequent Household Educational Investments }}$

Figure 2 shows education-related expenditures in 2004 by parental health status in 2000. On average, in this sample, households in which fathers reported the poorest health in the year 2000 spent about $434 \mathrm{RMB}$ on education four years later, compared to $858 \mathrm{RMB}$ among households with fathers reporting the best health; findings were similar for mother's health. Households with 
a chronically ill or disabled parent in 2000 spent about 684 RMB on education four years later, compared to about 817 RMB for households without a chronically ill or disabled parent. The gradient was much sharper for households with a disabled parent only, but the sample size for these kinds of households was small in the year 2000, at 79 households. 
Figure 2. Education-Related Expenditures in 2004 by Parental

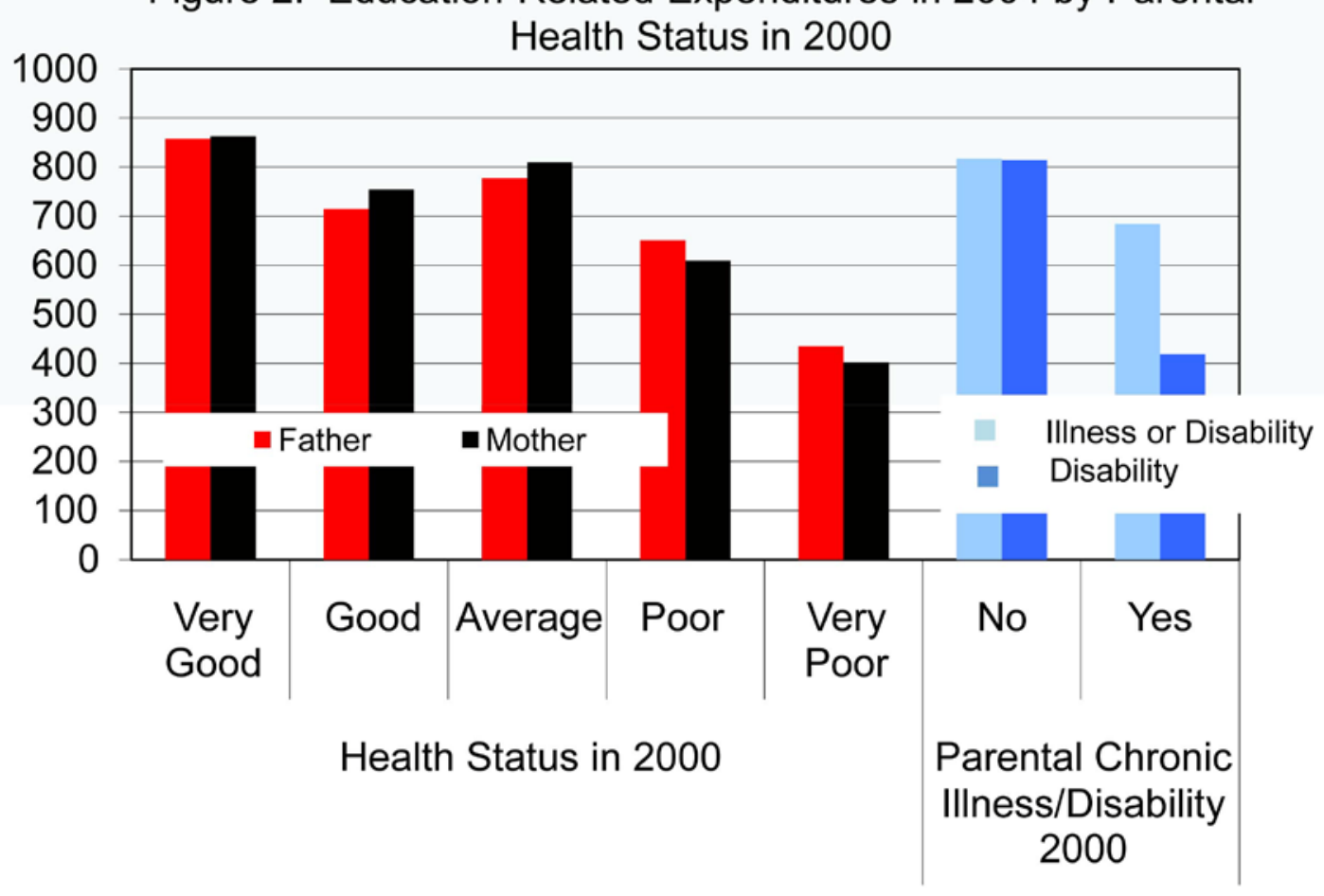


To account for household compositional differences, we investigated the same relationships in a multivariate context. Table 4 summarizes coefficients from a series of logged expenditure models that include an unadjusted bivariate model, a model adjusting for logged educational expenditures and children in 2000, and a model adjusting additionally for logged wealth in 2000. Two patterns emerge. Across the board, prior parental health measures show a significant, negative relationship with current educational expenditures. Second, the relationship appears to weaken in the models in which wealth in the year 2000 is taken into account.

Table 4. Coefficients for Parental Illness Measures for Selected Models of Logged Educational Expenditures in 2004

\begin{tabular}{|c|c|c|c|}
\hline $\begin{array}{l}\text { Difference in } 2004 \text { Logged } \\
\text { Educational Expenditures } \\
\text { (RMB) Associated with... }\end{array}$ & $\frac{\text { Model } 1}{\text { Unadjusted }}$ & $\begin{array}{c}\text { Model } 2 \\
\text { Adjusted for Prior } \\
\text { Expenditures, } \\
\text { Children in Home }\end{array}$ & $\begin{array}{c}\frac{\text { Model 3 }}{\text { Adjusted for Prior }} \\
\text { Expenditures, Wealth, } \\
\text { Children in Home }\end{array}$ \\
\hline $\begin{array}{l}\text { Mother's Poor Health in } 2000 \\
\text { (Compared to Good or } \\
\text { Ave.) }\end{array}$ & -0.44 & -0.42 & -0.32 \\
\hline $\begin{array}{l}\text { Father's Poor Health in } 2000 \\
\text { (Compared to Good or } \\
\text { Ave.) }\end{array}$ & -0.61 & -0.59 & -0.44 \\
\hline $\begin{array}{c}\text { Parental Chronic Illness } \\
\text { or Disability in } 2000\end{array}$ & -0.28 & -0.27 & -0.20 \\
\hline $\begin{array}{l}\text { Parental Disability } \\
\text { in } 2000\end{array}$ & -0.74 & -0.52 & -0.40 \\
\hline
\end{tabular}

Source: Wave 1 and Wave 2 GSCF, 2000 and 2004

Note: Models are linear regressions. Poor health variables for mothers and fathers are dummy variables representing fairly poor and very poor responses, compared to other responses. The disability coefficient is significant at $5 \%$ in model 3 ; all other coefficients significant at $1 \%$.

These findings speak to a clear relationship between prior health problems and current educational expenditures. This relationship weakens, but does not disappear, if the poorer economic status of the households with ill parents are taken into account. These patterns are consistent with the notion that parental ill health, and the economic hardship that often coincides with parental ill health, place children's education at risk.

Parental Ill Health and Borrowing 
Additional evidence of the link between ill health and economic constraints comes from Table 5, which shows that about one-third of children whose parents were chronically sick or disabled reported educational borrowing, compared to about one fifth of children with well parents. For children in households with a disabled parent, the borrowing rate was over 39 percent, compared to just over one-fifth of children in households with no disabled parents. For mothers' and fathers' general health status, about a third of children whose parents reported poor health, and about a fifth of children whose parents reported good health, had borrowed for education. In sum, parents who are chronically ill, disabled, or rate themselves as ill are much more likely to borrow money for education. This further buttresses the conclusion that ill parents were stretched to support their children's schooling, in economic terms. 
Table 5. Percent of Children's Families Reporting Having Borrowed Money to Pay School Fees by Parental Health Status

\begin{tabular}{|c|c|c|c|c|c|c|c|c|c|c|c|}
\hline & \multirow[t]{2}{*}{ Total } & \multicolumn{6}{|c|}{ General Health Status } & \multicolumn{2}{|c|}{$\begin{array}{c}\text { Parent is sick or } \\
\text { disabled }\end{array}$} & \multicolumn{2}{|c|}{ Parent is disabled } \\
\hline & & Poor & $\begin{array}{l}\text { Mothe } \\
\text { Ave. }\end{array}$ & Good & Poor & $\begin{array}{l}\text { Fathe } \\
\text { Ave. }\end{array}$ & Good & Yes & No & Yes & No \\
\hline $\mathbf{N}$ & $(\mathrm{N}=1,914)$ & $(\mathrm{N}=194)$ & $(\mathrm{N}=467)$ & $(\mathrm{N}=1,232)$ & $(\mathrm{N}=161)$ & $(\mathrm{N}=388)$ & $(\mathrm{N}=1,330)$ & $(\mathrm{N}=229)$ & $(\mathrm{N}=1,686)$ & $(\mathrm{N}=125)$ & $(\mathrm{N}=1,790)$ \\
\hline$\%$ & 22.52 & 32.47 & 22.48 & $20.71 * *$ & 31.06 & 25.52 & 20.32 ** & 33.47 & $20.98^{* *}$ & 39.37 & $21.32 * *$ \\
\hline
\end{tabular}

Source: Wave 2 GSCF, 2004 


\section{Other Potential Mechanisms Linking Parental Health and Children's Education}

\section{$\underline{\text { Labor Replacement }}$}

Other mechanisms might link parental illness to children's educational outcomes. One example would be that children whose parents are ill are 'replacing' parental labor. Table 2 shows that a child is significantly more likely to work for wages in households where mothers or fathers rate their health as being poor.

The gaps are sufficiently large as to be substantively interesting. For example, about 7 percent of children in households where mothers reported good health were working for wages, compared to about 13 percent of children in households where mothers reported poor health. Comparable figures for father's general health status were 7.14 percent and 14.29 percent. However, working for wages was not significantly related to parental chronic illness or disability. 
Table 6. Selected Logit Models of Child Work Status with General Health Status of Mother (Panel A) and Father (Panel B)

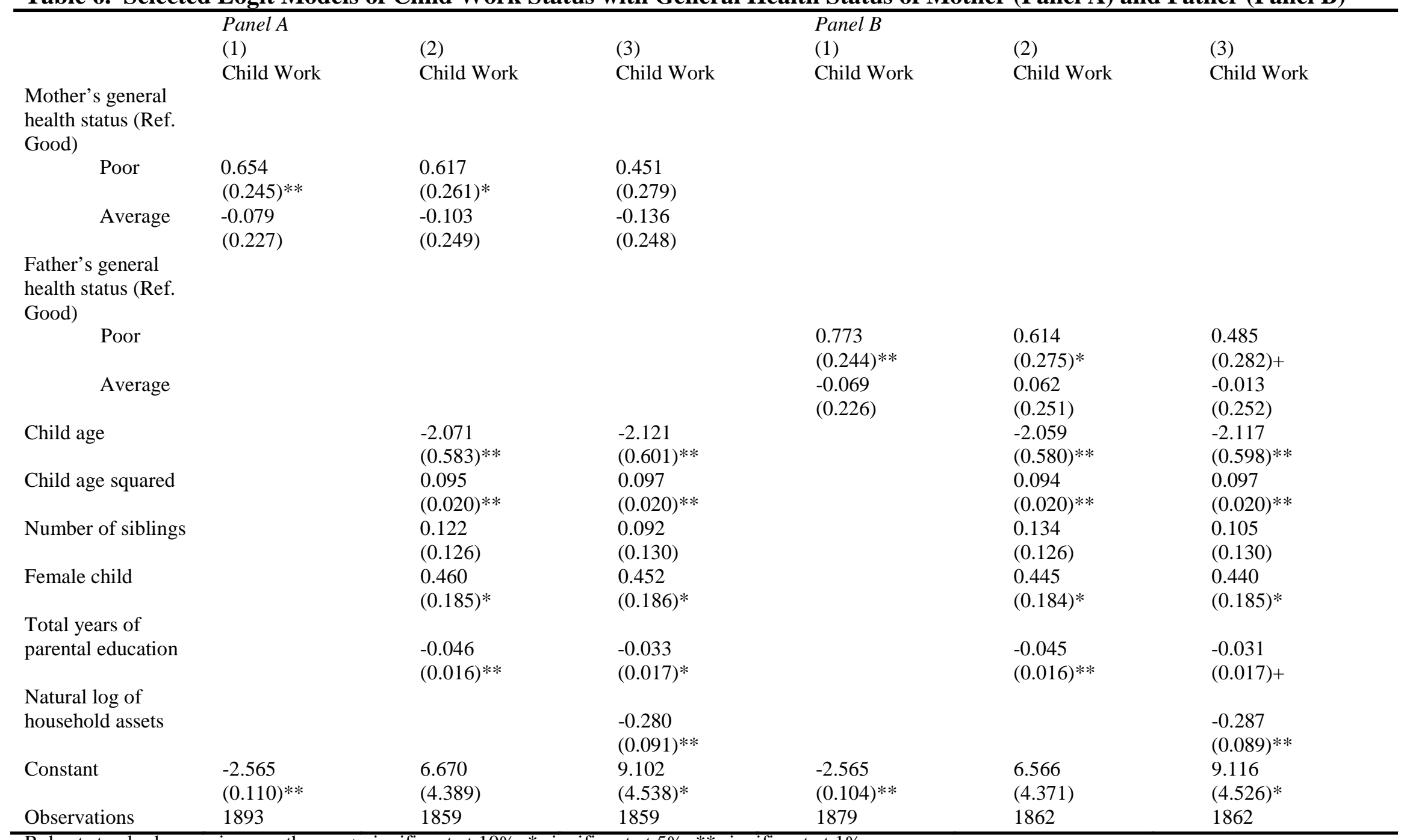

Robust standard errors in parentheses; + significant at $10 \%$; $^{*}$ significant at $5 \%$; ** significant at $1 \%$

Source: Wave 2 GSCF, 2004 
Table 6 shows multivariate results of models of whether or not the child works for wages. We find that whether or not children work for wages is significantly related to both mother's and father's general health status. For both measures, the coefficients in Model 1 suggested that about 7 percent of children with a parent in good health were working, compared to about 13 percent of children with a mother in poor health or about 14 percent of a father in poor health. These numbers represented a 92 percent increase in odds of working associated with poor health of a mother, or a 117 percent increase associated with poor health of a father, without controlling for other variables.

Introducing socio-demographic controls reduces the odds ratios associated with mother's and father's poor health, so that the odds increases associated with these variables were about 85 percent for Model 2 for both mother's and father's poor health. Finally, adding the wealth controls renders these findings insignificant for mother's poor health and marginally significant for father's health. In other words, children with ill parents are more likely to be working, on average, but this difference can be explained by their deeper impoverishment.

Another way that children may substitute for parental labor is by working in the household. Table 2 shows that for all parental health measures except parental disability, children with ill parents work significantly longer in the home than children without ill parents, with the difference ranging from about one to about three hours per week.

Interestingly, in terms of housework, children seem to be more likely to substitute for mother's labor. Net of socio-demographic and assets measures, having a mother in poor health is associated with 1.6 more hours of housework a week (see Table 7a, panel a). In the bivariate model, father's general health status shows a significant, though somewhat smaller, effect (Table 7a, panel b). The effect becomes marginal in Model 2, and insignificant when wealth is controlled. Results for disabled parents are non-significant, and results for parents with a longterm illness or disability are only significant in the bivariate context (Table 7b). 
Table 7a. Selected Regression Models of Time Child Spends on Housework with General Health Status of Mother (Panel A) and Father (Panel B)

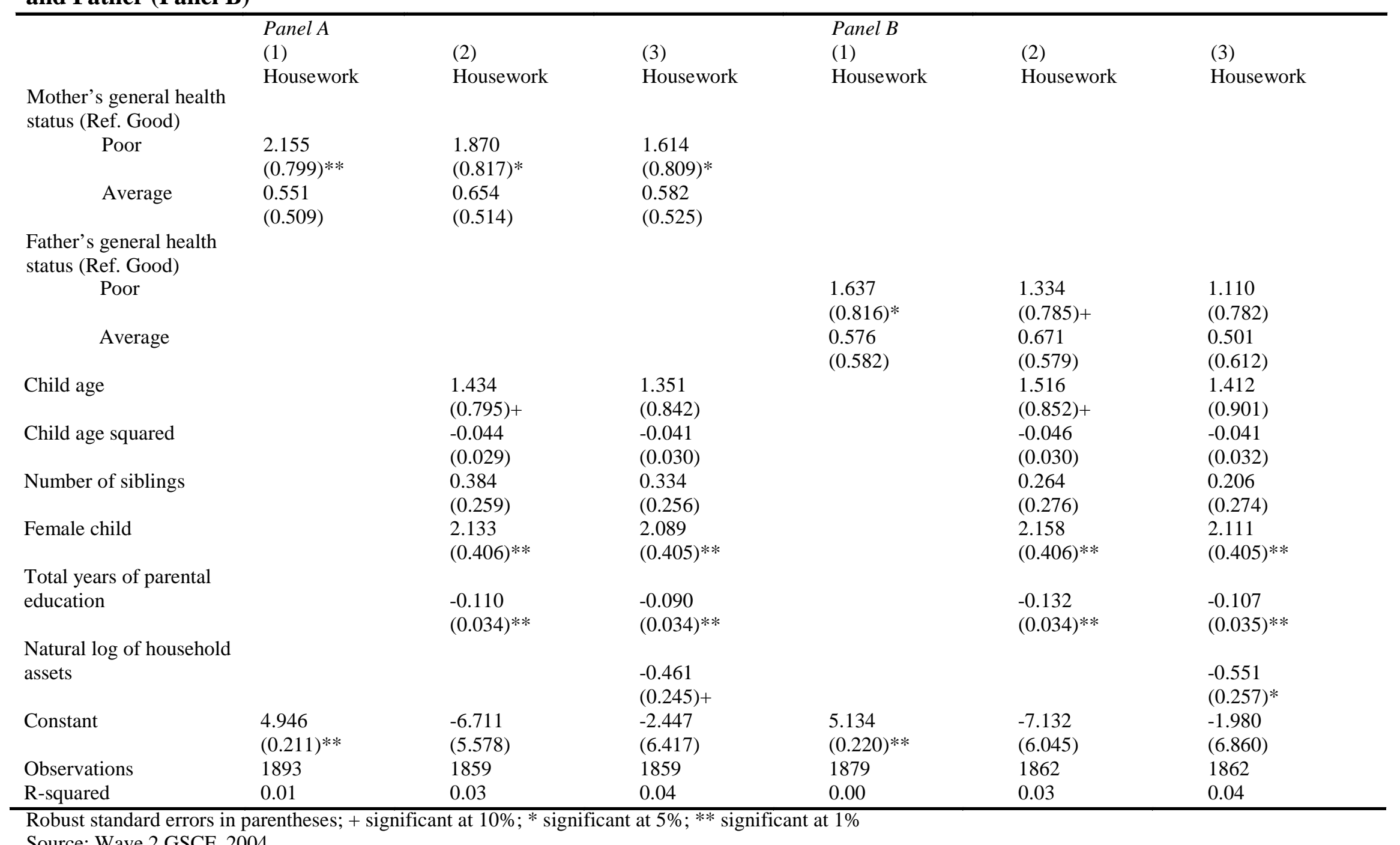

Source: Wave 2 GSCF, 2004 
Table 7b. Selected Regression Models of Time Child Spends on Housework with Parental Disability (Panel A) and Parental Illness/Disability (Panel B)

\begin{tabular}{|c|c|c|c|c|c|c|}
\hline & $\begin{array}{l}\text { Panel A } \\
\text { (1) }\end{array}$ & $(2)$ & (3) & $\begin{array}{l}\text { Panel B } \\
(1)\end{array}$ & $(2)$ & (3) \\
\hline Parent is disabled & $\begin{array}{l}\text { Housework } \\
1.104 \\
(0.775)\end{array}$ & $\begin{array}{l}\text { Housework } \\
1.034 \\
(0.767)\end{array}$ & $\begin{array}{l}\text { Housework } \\
0.760 \\
(0.776)\end{array}$ & Housework & Housework & Housework \\
\hline $\begin{array}{l}\text { Parent is sick or } \\
\text { disabled }\end{array}$ & & & & $\begin{array}{l}1.439 \\
(0.645)^{*}\end{array}$ & $\begin{array}{l}1.212 \\
(0.652)+\end{array}$ & $\begin{array}{l}1.005 \\
(0.670)\end{array}$ \\
\hline Child age & & $\begin{array}{l}1.495 \\
(0.833)+\end{array}$ & $\begin{array}{l}1.392 \\
(0.888)\end{array}$ & & $\begin{array}{l}1.451 \\
(0.827)+\end{array}$ & $\begin{array}{l}1.355 \\
(0.882)\end{array}$ \\
\hline Child age squared & & $\begin{array}{l}-0.045 \\
(0.030)\end{array}$ & $\begin{array}{l}-0.041 \\
(0.032)\end{array}$ & & $\begin{array}{l}-0.044 \\
(0.030)\end{array}$ & $\begin{array}{l}-0.040 \\
(0.031)\end{array}$ \\
\hline Number of siblings & & $\begin{array}{l}0.264 \\
(0.276)\end{array}$ & $\begin{array}{l}0.202 \\
(0.273)\end{array}$ & & $\begin{array}{l}0.265 \\
(0.277)\end{array}$ & $\begin{array}{l}0.206 \\
(0.275)\end{array}$ \\
\hline Female child & & $\begin{array}{l}2.172 \\
(0.408) * *\end{array}$ & $\begin{array}{l}2.120 \\
(0.406)^{* *}\end{array}$ & & $\begin{array}{l}2.151 \\
(0.405)^{* *}\end{array}$ & $\begin{array}{l}2.104 \\
(0.404)^{* *}\end{array}$ \\
\hline $\begin{array}{l}\text { Total years of } \\
\text { parental education }\end{array}$ & & $\begin{array}{l}-0.135 \\
(0.036)^{* *}\end{array}$ & $\begin{array}{l}-0.108 \\
(0.035)^{* *}\end{array}$ & & $\begin{array}{l}-0.133 \\
(0.036)^{* *}\end{array}$ & $\begin{array}{l}-0.107 \\
(0.035)^{* *}\end{array}$ \\
\hline $\begin{array}{l}\text { Natural log of } \\
\text { household assets }\end{array}$ & & & $\begin{array}{l}-0.577 \\
(0.250)^{*}\end{array}$ & & & $\begin{array}{l}-0.561 \\
(0.253)^{*}\end{array}$ \\
\hline Constant & $\begin{array}{l}5.329 \\
(0.215)^{* *}\end{array}$ & $\begin{array}{l}-6.780 \\
(5.869)\end{array}$ & $\begin{array}{l}-1.477 \\
(6.668)\end{array}$ & $\begin{array}{l}5.229 \\
(0.216)^{* *}\end{array}$ & $\begin{array}{l}-6.502 \\
(5.818)\end{array}$ & $\begin{array}{l}-1.373 \\
(6.619)\end{array}$ \\
\hline Observations & 1915 & 1862 & 1862 & 1915 & 1862 & 1862 \\
\hline R-squared & 0.00 & 0.03 & 0.04 & 0.00 & 0.03 & 0.04 \\
\hline
\end{tabular}

Source: Wave 2 GSCF, 2004 


\section{$\underline{\text { Children's Educational Behaviors }}$}

\section{ATTENDANCE}

Turning to measures of children's education-related behaviors and performance, we consider children's absence and their math or language scores. For absence, almost 11 percent of children of mothers with poor health had been absent, compared to just four percent of children of mothers who report good health (see Table 2). There is no evidence of differences in absence associated with father's ill health or parental chronic disability and illness.

We modeled absence against mother's health (Table 8). These tables follow the same structure as earlier multivariate tables, with the first specification showing only maternal health as a predictor, the second specification adding socio-demographic controls, and the third specification adding logged assets as a wealth measure. Children with a mother who reported poor health had odds of absence that were significantly higher than those of children of mothers reporting good health - 2.66 times higher in the model controlling for socio-demographic characteristics and logged assets. These findings suggest that mothers who are ill may be exerting a different impact than fathers who are ill: ill mothers may be unable to supervise children, or children may need to substitute for the housework usually completed by mothers. 


\section{Table 8. Selected Logit Models of School Absence and General Health Status of Mother}

\begin{tabular}{|c|c|c|c|}
\hline & (1) & (2) & (3) \\
\hline & Absent & Absent & Absent \\
\hline \multicolumn{4}{|c|}{$\begin{array}{l}\text { Mother's general health } \\
\text { status (Ref. Good) }\end{array}$} \\
\hline Poor & $\begin{array}{l}0.991 \\
(0.301)^{* *}\end{array}$ & $\begin{array}{l}0.968 \\
(0.317)^{* *}\end{array}$ & $\begin{array}{l}0.979 \\
(0.328) * *\end{array}$ \\
\hline Average & $\begin{array}{l}0.569 \\
(0.244)^{*}\end{array}$ & $\begin{array}{l}0.626 \\
(0.247) *\end{array}$ & $\begin{array}{l}0.629 \\
(0.249) *\end{array}$ \\
\hline \multicolumn{4}{|c|}{$\begin{array}{l}\text { Father's general health status } \\
\text { (Ref. Good) }\end{array}$} \\
\hline \multicolumn{4}{|l|}{ Average } \\
\hline Child age & & $\begin{array}{l}2.259 \\
(2.433)\end{array}$ & $\begin{array}{l}2.261 \\
(2.430)\end{array}$ \\
\hline Child age squared & & $\begin{array}{l}-0.069 \\
(0.081)\end{array}$ & $\begin{array}{l}-0.069 \\
(0.081)\end{array}$ \\
\hline Number of siblings & & $\begin{array}{l}0.414 \\
(0.140)^{* *}\end{array}$ & $\begin{array}{l}0.415 \\
(0.140)^{* *}\end{array}$ \\
\hline Female child & & $\begin{array}{l}0.085 \\
(0.200)\end{array}$ & $\begin{array}{l}0.088 \\
(0.200)\end{array}$ \\
\hline Total years of parent & & & \\
\hline Education & & $\begin{array}{l}-0.001 \\
(0.019)\end{array}$ & $\begin{array}{l}-0.001 \\
(0.019)\end{array}$ \\
\hline Natural log of house & & & \\
\hline Assets & & & $\begin{array}{l}0.020 \\
(0.102)\end{array}$ \\
\hline Constant & $\begin{array}{l}-3.114 \\
(0.158) * *\end{array}$ & $\begin{array}{l}-22.086 \\
(18.244)\end{array}$ & $\begin{array}{l}-22.264 \\
(18.252)\end{array}$ \\
\hline Observations & 1652 & 1626 & 1626 \\
\hline
\end{tabular}

\section{ACADEMIC PERFORMANCE}

In the bivariate tables, children in households with mothers who report poor health have significantly lower scores in math and language than children in other households (see Table 2). Other parental health measures do not show relationships with school achievement that are statistically significant at conventional levels.

We pursued the findings for mothers in a multivariate model. For mother's general health status and math achievement, significant, sizeable negative effects are present. The Model 2 specification suggests that, net of socio-demographic characteristics, having a mother whose health is poor, compared to a mother whose health is good, is associated with a math test score reduction of 2.191 points, or 17.7 percent of a standard deviation. However, the effect drops to 
insignificance when logged assets are controlled (see Table 9). For language, mother's general health status was significant only in the bivariate model; we do not present this model here.

Table 9. Selected Regression Models of Math Achievement and General Health Status of Mother

\begin{tabular}{llll} 
& $(1)$ & $(2)$ & $(3)$ \\
Mother's general & Math Score & Math Score & Math Score \\
health status (Ref. & & & \\
Good) & & & \\
\multicolumn{1}{c}{ Poor } & -2.774 & -2.191 & -1.767 \\
& $(1.053)^{* *}$ & $(1.057)^{*}$ & $(1.079)$ \\
\multicolumn{1}{c}{ Average } & 1.160 & 1.004 & 1.110 \\
& $(0.684)+$ & $(0.687)$ & $(0.685)$ \\
Child age & & 2.672 & 2.726 \\
& & $(3.701)$ & $(3.698)$ \\
Child age squared & & -0.088 & -0.091 \\
& & $(0.125)$ & $(0.125)$ \\
Number of siblings & & 0.697 & 0.773 \\
& & $(0.458)$ & $(0.461)^{+}$ \\
Female child & & 1.375 & 1.438 \\
& & $(0.617)^{*}$ & $(0.619)^{*}$ \\
Total years of & & & \\
parental education & & 0.312 & 0.285 \\
& & $(0.056)^{* *}$ & $(0.057)^{* *}$ \\
Natural log of & & & \\
household assets & & & 0.686 \\
& & & $(0.295)^{*}$ \\
Constant & 73.716 & 48.376 & 42.550 \\
& $(0.402)^{* *}$ & $(27.391)^{+}$ & $(27.621)$ \\
Observations & 1628 & 1600 & 1600 \\
R-squared & 0.01 & 0.03 & 0.04 \\
\hline
\end{tabular}

Robust standard errors in parentheses; + significant at 10\%; * significant at 5\%; ** significant at $1 \%$ Source: Wave 2 GSCF, 2004

Overall, these measures suggest that children's educational behaviors - measured as absenteeism - are affected by having ill mothers, more than ill fathers. Regarding performance, father's measures never mattered, but mother's measures did for math. The fact that the mother's ill health effect for math dissipates with inclusion of logged assets suggests that for this relationship, mother's ill health is signaling households with the fewest resources to support children's schooling.

\section{Conclusions}

Poor health is detrimental to individual economic productivity and welfare, and probably especially so in poorer, developing country settings (Strauss and Thomas, 1998). In such settings, diseases that affect infants and children are prevalent, and carry their effects into adulthood, impacting the entire lifecycle. Moreover, in lower income economies, a higher proportion of the employment opportunities demand heavy physical labor, which requires good health, strength and endurance of employees. Thus, in these settings, the poor are both more 
likely to suffer from severe health problems resulting from disease or lack of adequate nutrition, and also more likely to be working in jobs that require greater physical strength.

This paper has also sought to address the question of whether the well-established economic costs of poor health among adults may translate into poorer human capital acquisition in the next generation. In rural Gansu, poor parental health is strongly associated with poverty: children in the poorest quintile were over twice as likely to have a father who reported poor health as were children in the wealthiest. Moreover, parental health problems were a significant signal of risk for reduced enrollment: 77 percent of children whose fathers reported poor health were enrolled, compared with about 88 percent of children of fathers with average or good health, and the disadvantage of having an ill father persisted in multivariate analyses that accounted for sociodemographic background and assets. Ill parents are more likely to report borrowing for their children's education, and prior parental ill health is associated with reduced household educational spending. These examples suggest that social sector policies of the reform era policies that created cost barriers for accessing health care and education - have likely affected the mechanisms of poverty creation, and the transmission of poverty across generations in rural Gansu.

In the impoverished rural population of Gansu, there are also indirect ways that having ill parents can interfere with children's focus on schooling. Mother's illness may affect children through reduced attendance at school, as children's likelihood of absenteeism is greater with ill mothers. This may be an issue of reduced supervision, or it may be that children are staying home to help or care for ill mothers. Results also suggest that, on average, children with ill parents are more likely to take up paid labor, but this effect is explained by the economic vulnerability of the households in which these children live. More consistent evidence suggests that children are substituting for labor at home when mothers are ill. These findings indicate the importance of considering the types of labor that children are involved in, whether or not this work is harmful to children's health, and whether it facilitates, impedes, or is neutral with regard to the acquisition of skills or credentials that may enable these children to sustain themselves as adults in the future.

However, our main results about educational access speak to the importance of cost barriers in health and education. An important question is whether these barriers are changing. In education, it is likely that the answer is 'yes'. While overall educational trends indicate a continuing expansion of access, in contrast to the more concerning trends in public health, concerns about the impact of cost barriers to access in recent years have led to government action. In 2003, the State Council held the first national working conference since 1949 to formulate plans for the development of rural education, with a focus on protecting access to and improving the quality of compulsory education in rural areas (Postiglione, 2006). Among the ideas to emerge from the conference were plans to establish an effective system of sponsorship for poor students receiving compulsory education, such as by exempting poor students from all miscellaneous fees and textbook charges and offering them lodging allowances by the year 2007.

In March of 2004, the State Council approved and circulated the 2003-2007 Action Plan for Revitalizing Education, called the New Action Plan (State Council, 2004). One of the strategic priorities of the New Action Plan is the implementation of compulsory education in rural areas. 
In 2005, it was announced that the government would spend 218 billion RMB to help improve education in rural areas in the succeeding five years (CERNET, 2005a). By 2007, the government committed to eliminating educational tuition and fees and providing free textbooks and subsidies for needy rural students in compulsory education (CERNET, 2005a; though see CERNET, 2005b for a different timeline for eliminating fees). More recently, during the $10^{\text {th }}$ National People's Congress, Chinese Premier Wen Jiabao pledged to 'eliminate all charges on rural students receiving 9-year compulsory education before the end of 2007' (People's Daily March 5, 2006). In June of 2006, the Standing Committee of the National People's Congress approved an Amendment to the Compulsory Education Law that gives rural children the right to nine years of free compulsory education (Xinhua News Service June 29, 2006). If successful, this initiative will largely remove the educational cost burden on rural families for obtaining compulsory schooling. Cost barriers beyond compulsory-level schooling remain significant.

In the realm of health, whether changes to reduce the cost burden on poor families are emerging is less certain. Government concerns about the public health system are deep, and have prompted unusually frank criticism of reform policies in recent years. For example, in 2005, the World Health Organization and the State Council published a report criticizing the current status of the public health system and stating that the action to universalize access to basic services in education have yet to materialize in the realm of public health (Office of the World Health Organization Representative in China, and Social Development Department of the State Council Development Research Group, 2005). Experiments are under way to address some of these problems. In 2002, officials launched experiments to create a very rudimentary financial safety net for health care, in which the government would provide the equivalent of 2.50 USD a year to help cover a basic insurance plan for peasants, who would match this with an annual 1.25 USD of their own (Blumenthal and Hsiao, 2005). These plans cover only inpatient care, with a very high deductible, and leave peasants without adequate primary care services and drugs. They are being implemented in 300 of China's more than 2000 counties, and will be rolled out to the rest of the country by 2010 (Blumenthal and Hsiao, 2005).

Our findings have suggested that the barriers to health care faced by rural parents - in combination with the costs of education - mean that ill health may have a 'spillover' effect on the long-term educational (and thus economic) prospects of the next generation. A change in this situation depends heavily on the success of initiatives to reduce health care and education cost burdens on the poor. 


\section{References}

Ainsworth, Martha, Kathleen Beegle, and Godlike Koda 2005, The Impact of Adult Mortality and Parental Deaths on Primary Schooling in North-Western Tanzania, The Journal of Development Studies, vol. 41, no. 3, 412-39.

Alderman, H., Jere Behrman, V. Lavy, and R. Menon 2001, Child Health and School Enrollment, Journal of Human Resources, vol. 36, no. 1, 185-205.

Beach, Marilyn 1997, China’s Rural Health Care Gradually Worsens, The Lancet, no. 358, 56768.

Beegle, Kathleen 2005, Why Should We Care About Child Labor? The Education, Labor Market, and Health Consequences of Child Labor. Washington D.C.: World Bank.

Behrman, Jere 1996, The Impact of Health and Nutrition on Education, World Bank Research Observer, vol. 11, no. 1, 25-37.

Blumenthal, David, and William Hsiao 2005, Privatization and its Discontents - the Evolving Chinese Health Care System, The New England Journal of Medicine, vol. 353, no. 11, 1165-70.

Blunch, Niels-Hugo 2006, Children's Work and School Attendance in Ghana, in Research in the Sociology of Education 15: Children's Lives and Schooling across Societies, Ed. Emily Hannum and Bruce Fuller, Oxford: Elsevier/JAI, 2006, 177-205.

CERNET 2005a, China to Spend 218 Bln Yuan Promoting Rural Education. Available at <http://www.edu.cn/20051227/3167788.shtml $>$ (2005). [07/07/2006].

CERNET 2005b, Rich-Poor Education Gap to be Addressed. Available at <http://www.edu.cn/20051130/3163495.shtml> (2005). Accessed 07/07/2006.

Ersado, Lire 2005, Child Labor and Schooling Decisions in Urban and Rural Areas: Comparative Evidence from Nepal, Peru, and Zimbabwe, World Development, vol. 33, no. 3, 455-80.

Fiscella, Kevin, Peter Franks, Marthe Gold, and Carolyn Clancy 2000, Inequality in Quality: Addressing Socioeconomic, Racial, and Ethnic Disparities in Health Care, JAMA, vol. 283, 2579-84.

Gao, J., S. Tang, R. Tolhurst, and K. Rao 2001, Changing Access to Health Services in Urban China: Implications for Equity, Health Policy and Planning, vol. 16, no. 3, 302-12.

Glewwe, Paul, Hanan G. Jacoby, and Elizabeth King 2001, Early Childhood Nutrition and Academic Achievement: A Longitudinal Analysis, Journal of Public Economics, vol. 81, 345-68. 
Glewwe, Paul 2005, The Impact of Child Health and Nutrition on Education in Developing Countries: Theory, Econometric Issues, and Recent Empirical Evidence, Food and Nutrition Bulletin, vol. 26, no. 2-supplement 2, S235-S50.

Gustafsson, Bjorn, and Shi Li 2004, Expenditures on Education and Health Care and Poverty in Rural China, China Economic Review, vol. 15, 292-301.

Hannum, Emily, Jere Behrman, Meiyan Wang and Jihong Liu 2008, Education in the Reform Era, in China's Economic Transition, ed. Loren Brandt and Thomas Rawski, Cambridge: Cambridge University Press, 215-249.

Hawkins, J. N. 2000, Centralization, Decentralization, Recentralization: Educational Reform in China, Journal of Educational Administration vol. 38, no. 5, 442-55.

Hsiao, William, Dean T. Jamison, William P. McGreevey, and Winnie Yip 1997, Financing Health Care: Issues and Options for China. Washington D.C.: World Bank.

Kaufman, J. 2005, China: The Intersections between Poverty, Health Inequity, Reproductive Health and HIV/AIDS, Development, vol. 48, no. 4, 113-9.

Lindelow, Magnus, and Adam Wagstaff 2005, Health Shocks in China: Are the Poor and Uninsured Less Protected?. Vol. 3740. Washington, D.C.: The World Bank.

Liu, Xingzhu, and Anne Mills 2002, Financing Reforms of Public Health Services in China: Lessons for Other Nations, Social Science and Medicine, vol. 54, no. 11, 1619-98.

Liu, Y., and W. C. Hsiao 2001, China's Poor and Poor Policies: The Case of Rural Health Insurance, Conference on Financial Sector Reform in China, Cambridge, MA., Harvard School of Public Health.

Liu, Y., K. Rao, and W. C. Hsiao 2003, Medical Expenditure and Rural Impoverishment in China, Journal of Health, Population, and Nutrition, vol. 21, no. 3, 216-22.

National Bureau of Statistics (China) 1997, China Statistics Yearbook 1996. Electronic edition available at <http://www.stats.gov.cn/english/statisticaldata/yearlydata/YB1996e/index1.htm>. Accessed 11/15/2006.

National Bureau of Statistics (China) 2006, China Statistical Yearbook 2005. Electronic edition available at $<$ http://www.stats.gov.cn/tjsj/ndsj/2005/indexee.htm>. Accessed 11/15/2006.

Office of the World Health Organization Representative in China, and Social Development Department of the State Council Development Research Group 2005, China: Health, Poverty, and Economic Development. Beijing: World Health Organization and State Council. Available at $<$ http://www.who.int/entity/macrohealth/action/CMH_China.pdf $>$. Accessed11/15/2006. 
People's Daily 5 March 2006, China Pledges Elimination of Rural Compulsory Education Charges in Two Years, People's Daily Online. Available at <http://english.peopledaily.com.cn/200603/05/eng20060305_248042.html>.Accessed 8/18/2009.

Postiglione, G. 2006, School Access and Equity in Rural Tibet, Education and Reform in China, Ed. Emily Hannum and Albert Park, London: Routledge, 2006, 97-116.

Schultz, T. Paul, and Aysit Tansel 1997, Wage and Labor Supply Effects of Illness in Cote d'Ivoire and Ghana: Instrumental Variable Estimates for Days Disabled, Journal of Development Economics, vol. 53, 251-86.

State Council, 2004, 2003-2007 Action Plan for Revitalizing Education.

Strauss, John, and Duncan Thomas 1998, Health, Nutrition, and Economic Development, Journal of Economic Literature, vol. 36, no. 2, 766-817.

Thomas, Duncan, and John Strauss 1997, Health and Wages: Evidence on Men and Women in Urban Brazil, Journal of Econometrics, vol. 77, 159-85.

Tsang, M. C. 2000, Education and National Development in China since 1949: Oscillating Policies and Enduring Dilemmas, China Review-an Interdisciplinary Journal on Greater China, 579-618.

United Nations Economic and Social Commission for Asia and the Pacific (UNESCAP). Population and Family Planning in China by Province: Gansu Province. Available at $<$ http://www.unescap.org/esid/psis/population/database/chinadata/gansu.htm>.

Accessed 11/15/2006.

Wagstaff, Adam 2002, Poverty and Health Sector Inequalities, Bulletin of the World Health Organization, vol. 80, no. 2, 97-105.

Wang, Hong, Licheng Zhang, and William Hsiao 2006, Ill Health and its Potential Influence on Household Consumptions in Rural China, Health Policy, vol. 78, no. 2, October, 167-77.

Wang, Sangui 2004, Poverty Targeting in the People's Republic of China, Asian Development Bank Institute Discussion Paper No. 4, Tokyo: Asian Development Bank Institute.

Woo, Wing Thye, and Shuming Bao 2003, China: Case Study on Human Development Progress Towards the Millennium Development Goals at the Subnational Level (Background Paper for the Human Development Report 2003). New York: United Nations Development Programme Human Development Report Office.

Xinhua News Service, 29 June 2006, China Adopts Amendment to Compulsory Education Law, Xinhua Online. Available at <http://news.xinhuanet.com/english/200606/29/content_4768807.htm>. Accessed 8/18/2009. 
Yu, H., S.H. Cao, and H. Lucas 1997, Equity in the Utilization of Medical Service: A Survey of Poor in China, IDS Bulletin, vol. 28, no. 1, 16-23.

Yu, Shengchao and Emily Hannum 2007, Food for Thought: Poverty, Family Nutritional Environment, and Children's Educational Performance in Rural China, Sociological Perspectives, vol. 50, 53-77. 


\section{Appendix 1: Measuring Health in Surveys}

Measuring health in the context of a social survey is difficult. Strauss and Thomas (1998) have offered a comprehensive assessment of frequently used indicators of health status in surveys. Here, we summarize their assessment of major strategies that have been employed and important caveats about those strategies. Strauss and Thomas (1998) consider indicators including selfreported general health status, self-reported morbidities, limitations to normal activities, measures of physical functioning, and finally, nutrition-based health measures. Strauss and Thomas (1998) advocate the use of multiple health indicators. We adopt two in this paper, as we describe below.

\section{General Health Status}

General health status is one of the most frequently-used health indicators. It relies on individual self-assessment (or, in some cases, significant other's assessment) of health status. It is considered a reasonable measure of health status in that it has been found to be correlated with subsequent morbidity and mortality. Weaknesses of this measure include its inability to capture the complexity of health, and its inherent subjectivity. Those populations with less health awareness and less access to healthcare - that is, more disadvantaged populations that are likely to have poorer health status - may tend to report better health by this type of measure. Strauss and Thomas (1998) conclude that while this measure does provide some information, it is likely to be biased due to its correlation with socioeconomic status.

\section{$\underline{\text { Morbidities and Illness }}$}

This type of indicator relies on reports of illness or specific morbidities and symptoms such as fever, diarrhea, respiratory problems, or disability. These measures are problematic, if what counts as an illness is different for different respondents. Strauss and Thomas (1998) find that these indicators, too, are biased with respect to socioeconomic status: poorer people are less likely to have these sorts of illnesses diagnosed, and thus tend to report fewer illnesses.

\section{Limitations to Normal Activities}

Respondents report about the extent to which they were precluded from their normal activities during a specified time period. This measure, too, may be correlated with socioeconomic status. Strauss and Thomas (1998) hypothesize that members of higher socioeconomic status groups face higher opportunity costs for not engaging in their normal daily activities.

\section{Physical Functioning}

A common indicator of physical functioning is the so-called activities of daily living (ADLs) measure, which is a self report of the ease or difficulty with, which an individual can engage in activities that would be effortless for a person in good health. These include items such as ability to walk a specified distance, lifting a particular weight, bending, or climbing stairs. Strauss and 
Thomas (1998) indicate that ADL-type measures may have limited usefulness in dealing with working-age adults, and tend to be more useful in studies of aging populations.

\section{Nutrition-based Health Measures}

These measures include data on nutrition intake, such as respondent reports of ingredients in all meals taken in the past 24 hours, and nutrition output in the form of anthropometric measurements of height, weight and body mass index (BMI).

In this paper, we make use of general health status and reported illnesses. We do not look at nutritional intake measures, nor anthropometric measures, as these are better long-term indicators of nutrition (especially nutrition in childhood) than indicators of health problems in the recent past. Due to the potential socioeconomic bias in the measures that we use, it is possible that we are underestimating the coincidence of poverty and ill health. 